\title{
Effectiveness of Music Therapy on Quality of Sleep among Elderly Residing at Selected Old Age Home, Chennai
}

\author{
V. Hemavathy ${ }^{1}$, K. Muthamizh Selvan ${ }^{2}$ \\ Principal, Sree Balaji College of Nursing, Bharat University, Chennai, India \\ II ndYear M.Sc Nursing, Sree Balaji College of Nursing, Bharat University, Chennai, India
}

\begin{abstract}
Background of the Study: Aging is an inevitable developmental phenomenon bringing along a number of changes in the physical, psychological, hormonal and social conditions. sleeplessness is an common psychiatric problem in the old age that is often misdiagnosed and untreated . Objectives: To assess the quality of sleep among elderly residing. Evaluate the effectiveness of music therapy on quality of sleep among elderly residing. Find association between quality of sleep with selected demographic variables in elderly residing. Hypothesis: There will be significant difference between the pre-and post-test scores in the quality of sleep among elderly residing. Methodology: Pre -experimental one group pre-test and post-test design was selected for this study. Purposive sampling technique was used for the study. Final Result And Conclusion: In thepretest 2(6.7\%) of them had good quality of sleep, 13(43.3\%) of them had fair quality of sleep and 15(50\%) of them had poor quality of sleep, whereas in posttest 14(46.7\%) of them had good quality of sleep, 12(40\%) of them had fair quality of sleep and 4(13.3\%) of them had poor quality of sleep. . The pre test mean score was 33.1 and the post test mean score was 16.7. The calculated $t$ value 14.3 at $p \leq 0.05$ level was significantly higher than the table value 2.05 at $p \leq 0.05$ level which shows that music therapy was effective in improving the quality of sleep.
\end{abstract}

Keywords: quality of sleep, effectiveness, music therapy, elderly, old age home

\section{Introduction}

Aging is an inevitable developmental phenomenon bringing along a number of changes in the physical, psychological, hormonal and social conditions, Sleep disturbances are the most common mental disorders reported among the older people in various countries. Complaints of sleep disturbances, such as insomnia, sleep fragmentation and daytime sleepiness are common in the general population and estimated at $35 \%$, with an even higher prevalence $(50 \%)$ in older people. More studies have reported that loss of sleep in older people is associated with a greater risk of adverse outcomes, including accidents, falls, and poor health status and all-cause mortality, Music has many purposes. Its multidimensional nature touches the individual's physical and psychological levels of consciousness suggested that music exerts its effect through the entrainment of body rhythms.

\subsection{Objectives}

- To assess the quality of sleep among elderly at selected old age home.

- To evaluate the effectiveness of music therapy on the quality of sleep among the elderly at selected old age home.

- To associate the quality of sleep among elderly at selected old age home with their selected demographic variables

\subsection{Hypothesis}

$\mathrm{H}_{1}$ : There will be a significant difference in the pre and post test scores on quality of sleep among elderly
$\mathrm{H}_{2}$ : There will be a significant association in the quality of sleep among elderly and their Selected demographic variables

\section{Methodology}

Pre-experimental one group pre-test and post-test design was selected for this study in sivanandasaraswathi old age home, Chennai. The study population will comprise of elderly residents in selected old age home, Total sample size 30 both male and female elderly patients are selected for the study by non probability convenience sampling technique. The questionnaire has 2 parts consisting of Demographic variables these are age, sex, marital status, religion ,present medical illness, duration of stay, education, mode of entry, visitin the second part of questionnaire modified Pittsburgh Quality of sleep index scale(short form) consisting of 15 items `was used Interpretation of score was done as follow

Table 1: Scoring Procedure for Quality of Sleep

\begin{tabular}{|c|c|c|}
\hline Quality of sleep & Score & Percentage \\
\hline Good quality of sleep & $0-15$ & $0-33 \%$ \\
\hline Fair quality of sleep & $16-30$ & $34-66 \%$ \\
\hline Poor quality of sleep & $31-45$ & $67 \mathrm{Above} \%$ \\
\hline
\end{tabular}

\section{Result}

Table 2: Pre Test Quality of Sleep

\begin{tabular}{|c|c|c|}
\hline \multirow{2}{*}{ Pretest quality of sleep } & \multicolumn{2}{|c|}{ Pre-Test } \\
\cline { 2 - 3 } & No & Percentage (\%) \\
\hline Good quality of sleep & 2 & 6.7 \\
\hline Fair quality of sleep & 13 & 43.3 \\
\hline Poor quality of sleep & 15 & 50 \\
\hline Total & 30 & 100 \\
\hline
\end{tabular}




\section{International Journal of Science and Research (IJSR) \\ ISSN (Online): 2319-7064 \\ Index Copernicus Value (2013): 6.14 | Impact Factor (2014): 5.611}

Reveals that among 30 samples 2(6.7\%) had good quality of sleep , 13( $43.3 \%)$ had fair quality of sleep and $15(50 \%)$ of them had poor quality of sleep in the pre test.

Table 3: post test quality of sleep among elderly residing

\begin{tabular}{|c|c|c|}
\hline \multirow{2}{*}{ Pretest quality of sleep } & \multicolumn{2}{|c|}{ Post-Test } \\
\cline { 2 - 3 } & No & Percentage (\%) \\
\hline Good quality of sleep & 14 & 46.7 \\
\hline Fair quality of sleep & 12 & 40 \\
\hline Poor quality of sleep & 4 & 13.3 \\
\hline Total & 30 & 100 \\
\hline
\end{tabular}

Reveals that among 30 samples 14(46.7\%) had good quality of sleep , 12( 40\%) had fair quality of sleep and 4(13.3\%) of them had poor quality of sleepin the posttest.

Table 4: comparison of pre test and post test quality of sleep among Elderly residents

\begin{tabular}{|c|c|c|c|c|c|}
\hline \multirow{2}{*}{ Quality of sleep } & \multicolumn{2}{|c|}{ Pre-Test } & \multicolumn{2}{|c|}{ Post-Test } & \multirow{2}{*}{$\begin{array}{c}\text { Chi- } \\
\text { square }\end{array}$} \\
\hline & $\mathrm{No}$ & Percentage & No & Percentage & \\
\hline Good quality of sleep & 2 & 6.7 & 14 & 46.7 & \multirow{4}{*}{$\mathrm{T}=14.3$} \\
\hline Fair quality of sleep & 13 & 43.3 & 12 & 40 & \\
\hline Poor quality of sleep & 15 & 50 & 4 & 13.3 & \\
\hline Total & 30 & 100 & 30 & 100 & \\
\hline
\end{tabular}

Reveals the comparison of music therapy among quality of sleep .It shows that among 30 samples 2( 6.7\%) had good quality of sleep , 13( $43.3 \%$ ) had fair quality of sleep and 15( $50 \%$ ) of them had poor quality of sleep in the pre test.

30 samples 14( 46.7\%) had good quality of sleep , 12( $40 \%$ ) had fair quality of sleep and $4(13.3 \%)$ of them had poor quality of sleep in the post test, the effectiveness of music therapy among elderly the quality of sleep mean score was 33.1 in the pre -test, SD was 14.8 and mean post -test score was 16.7 and SD was 6.8 , so the total over all value reduction was 16.4 and SD was 8 with the paired t- test value is 14.3 and there is significant effectiveness at $P$ value is $2.05<0.05$

\section{Major Findings of the Study}

Among 30 samples 12 (40\%) of them belong to 61-70 years and $71-81$ years of age respectively, $18(60 \%)$ of them were female, $20(66.67 \%)$ were Hindus, $19(63.3 \%)$ of them were married, $15(50 \%)$ of them had primary education, $15(50 \%)$ of them stayed for 2-3 years, $18(60 \%)$ of them had visitors frequently, $20(66.67 \%)$ of them joined voluntarily in old age home, $9(30 \%)$ of them had diabetes, and $18(30 \%)$ had hypertension.

In the pre test, among 30 samples $2(6.7 \%)$ had good quality of sleep , 13( $43.3 \%$ ) had fair quality of sleep and 15( 50\%) of them had poor quality of sleep .In the post test, among 30 samples 14( 46.7\%) had good quality of sleep , 12( $40 \%)$ had fair quality of sleep and $4(13.3 \%)$ of them had poor quality of sleep .

\section{Conclusion}

- The pre-test mean score was 33.1, whereas the average post-test mean score was 16.7 andpaired ' $t$ ' test value was
14.3 at $p \leq 0.05$ level. The ' $t$ ' obtained value is higher than the table value (2.05). So it is proved that music therapy is effective on the quality of sleep among elderly.

- Significant association between the quality of sleep among elderly and their demographic variables like age, marital status, educational status, and duration of stay in old age home was obtained at $\mathrm{p} \leq 0.05$ level. Hence hypothesis $\mathrm{H}_{2}$ was retained for the above mentioned demographic variables.

\section{References}

[1] Bhatia. M.S. (2007). Text Book of Psychiatry. (3 ${ }^{\text {rd }}$ edition). New Delhi: C.B.S Publishers and Distributors.

[2] Burns, Nancy and Susan, K. Grove, (2004).The Practice of Nursing Research. Conduct,Crialle and Utilization, ( $5^{\text {th }}$ edition $)$, W. B Sunders Company, Philadelphia.

[3] Daniel. J, Buysse (2005)Review of sleep and psychiatry. $\left(1^{\text {st }}\right.$ edition $)$ Washington, American Psychiatry Publications.

[4] Denise.F.Polit (1999) Nursing Research Principles and Methods. Philadelphia. Lippincott.

[5] Gail.W.stuart, (2001).Principles and Practice of Psychiatric nursing, ( $7^{\text {th }}$ edition), Harcourt Private Limited. New Delhi.

[6] Gum, A.M. (2007) GerontologicalNursing(2 $2^{\text {nd }}$ edition) Philadelphia: Lippincott Publishers.

[7] Henry Kellerman, (1986). Text book of sleep disorder. New York, Mazel Publishers.

\section{Network References}

[8] www.pubmed.com

[9] www.medlineplus.com

[10] www.medsafe.com 